\title{
Diet of Procyon cancrivorus (Carnivora, Procyonidae) in restinga and estuarine environments of southern Brazil
}

\author{
Fernando M. Quintela ${ }^{1}$, Graziela Iob² \& Luiz G. S. Artioli ${ }^{3}$
}

\footnotetext{
1. Programa de Pós-Graduação em Biologia Animal, Universidade Federal do Rio Grande do Sul, Av. Bento Gonçalves 9.500, Bairro Agronomia, Porto Alegre, RS, Brazil, 91501-970. (corresponding author: fmquintela@yahoo.com.br)

2. Programa de Pós-Graduação em Ecologia, Universidade Federal do Rio Grande do Sul, Av. Bento Gonçalves 9.500, Bairro Agronomia, Porto Alegre, RS, Brazil, 91501-970. (grazielaiob@gmail.com)

3. Programa de Pós-Graduação em Biologia Animal, Universidade Federal do Rio Grande do Sul, Av. Bento Gonçalves 9.500, Bairro Agronomia, Porto Alegre, RS, Brazil, 91501-970. (lgartioli@hotmail.com)
}

\begin{abstract}
Despite its wide range and abundance on certain habitats, the crab-eating raccoon Procyon cancrivorus (G. Cuvier, 1798) is considered one of the less known Neotropical carnivore species. In the present study we analyzed the diet of P. cancrivorus in a peat forest and in an estuarine island in southernmost Brazil. Fruits of the gerivá palm tree Syagrus romanzoffiana were the most consumed item in the peat forest, followed by insects and mollusks. Small mammals, followed by Bromelia antiacantha (Bromeliaceae) fruits and brachyuran crustaceans were the most frequent items in the estuarine island. Other items found in lower frequencies were Solanum sp., Psidium sp., Smilax sp. and Dyospiros sp. fruits, diplopods, scorpions, fishes, anuran amphibians, reptiles (black tegu lizard and snakes), birds and medium-sized mammals (white-eared opossum, armadillo and coypu). Levin's index values (peat forest: 0.38; estuarine island: 0.45 ) indicate an approximation to a median position between a specialist and a well distributed diet. Pianka's index (0.80) showed a considerable diet similarity between the two systems. Procyon cancrivorus presented a varied diet in the studied areas and may play an important role as seed disperser on coastal environments in southernmost Brazil.
\end{abstract}

KEYWORDS. Bromelia antiacantha, crab-eating racoon, feeding habits, subtropical Brazil, Syagrus romanzoffiana.

RESUMO. Dieta de Procyon cancrivorus (Carnivora, Procyonidae) em ambientes de restinga e estuarino no Sul do Brasil. Apesar de sua ampla distribuição e abundância em determinados habitats, o mão-pelada Procyon cancrivorus (G. Cuvier, 1798) é considerado uma das menos conhecidas espécies de carnívoro Neotropical. No presente estudo analisamos a dieta de $P$. cancrivorus em uma mata paludosa e uma ilha estuarina no extremo sul do Brasil. Frutos da palmeira gerivá Syagrus romanzoffiana foi o item mais consumido na mata paludosa, seguido por insetos e moluscos. Pequenos mamíferos, seguidos por frutos de Bromelia antiacantha (Bromeliaceae) e crustáceos braquiúros foram os itens mais frequentes na ilha estuarina. Outros itens encontrados em menor frequência foram frutos de Solanum sp., Psidium sp., Smilax sp. and Dyospiros sp., diplópodos, escorpiões, peixes, anfíbios anuros, répteis (teiú e serpentes), aves e mamíferos de médio porte (gambá-da-orelha-branca, tatu e ratão-do-banhado). Os valores do índice de Levin (mata paludosa: 0.38; ilha estuarina: 0.45) indicam uma aproximação a uma posição mediana entre uma dieta especialista e bem distribuída. O índice de Pianka (0.80) mostrou uma considerável similaridade na dieta entre os dois sistemas. Procyon cancrivorus apresentou uma dieta variada nas áreas estudadas e pode desempenhar um importante papel como dispersor de sementes em ecossistemas costeiros no extremo sul do Brasil.

PALAVRAS-CHAVE. Bromelia antiacantha, mão-pelada, hábitos alimentares, Brasil subtropical, Syagrus romanzoffiana.

The crab-eating raccoon Procyon cancrivorus (G. Cuvier, 1798) is a medium sized procyonid widely distributed in the Neotropics, ranging from Costa Rica and Panama to Uruguay, northeastern Argentina and Brazil (CheiDa et al., 2011). It is a habitant of forest environments and open areas generally associated to limnic systems and oceanic shores (GonzÁLEZ \& LANFranco, 2010; Cheida et al., 2011).

Procyon cancrivorus is considered one of the less studied Neotropical carnivores (Morato et al., 2004; Cheida et al., 2011). A few studies on the species diet were conducted in Venezuela (BISBAL, 1986) and in restinga and Atlantic Forest areas of southeastern (GATTI et al., 2006) and southern Brazil (SANTos \& HARTZ, 1999; Martinellli \& Volpi, 2010; Pellanda et al., 2010; Aguiar et al., 2011). These investigations indicated that $P$. cancrivorus is a frugivorous-omnivorous species (PAgLia et al., 2012), with opportunistic feeding habits.

The restinga formations comprehend vegetal communities of sandy coastal areas and its physical elements (WAECHTER, 1985). In southern Brazil, these typical environments range from southern state of Santa Catarina to southernmost Rio Grande do Sul (WAECHTER, 1985; ARAúso, 1992). Most part of these areas are composed by Quaternary sedimentary basins, while some rocky outcrops from Pre-Cambrian to Jurassic are still present (WAEChter, 1985). In southern Rio Grande do Sul, the emerged segment of Quaternary sandy deposits is disrupted by the mouth of Patos lagoon estuary. This estuarine zone is characterized by a high biodiversity and biomass, resulted partly due to the input and mixing of alluvial and marine nutrients (SEELiger, 2010).

A compilation of mammalian records in Rio Grande do Sul forest and open restinga environments (FABIÁN et al., 2011) indicates the occurrence of 75 species, including 13 mesocarnivores. Mesocarnivores ( $<15$ kilograms) are apex predator in many environments and may play essential role in herbivores population control (RoEmER et al., 2009) and seed dispersal (GATTI et al., 2006). The present study investigated the diet of the mesocarnivore $P$. cancrivorus in restinga and estuarine environments in southern state of Rio Grande do Sul. We added new data to the knowledge 
on the species trophic ecology in coastal environments, through the sampling of a region never ever studied and the utilization of new indexes indicators of trophic tendencies.

\section{MATERIAL AND METHODS}

Study area. We conducted the study in the municipality of Rio Grande, located in the southern coastal plain of state of Rio Grande do Sul, southern Brazil. The climate in the region is classified as Cfa of Köppen, with temperatures varying from $9.5^{\circ} \mathrm{C}$ (minimum average) to $27.2^{\circ} \mathrm{C}$ (maximum average). The monthly precipitation average is $104 \mathrm{~mm}$ and the rainiest months are July, August and September, when precipitation average can reach 143 mm (VIEIRA, 1983).

Restinga forests represent typical vegetal communities in Rio Grande do Sul coastal plain, comprising formations such as peat and sandy forests. Restinga peat forests are characterized by the presence of water bodies permanently or periodically flooded by rainfall, without well-defined edges and with muddy soil (WAECHTER, 1985), while restinga sandy forests comprise arboreal formations developed over sandy substrate (ScHERER et al., 2005).Scat samples of $P$. cancrivorus were collected in two distinct restinga formations. One of them is a restinga peat forest fragment, locally known as "Mata da Estrada Velha" (32 ${ }^{\circ} 07^{\prime}$ ' ; 52 ${ }^{\circ} 09^{\prime} \mathrm{W}$ ) (Fig. 1). The vegetation is composed mainly by arboreal species [Erytrina crista-galli L., Syagrus romanzoffiana (Cham.) Glassman, Ficus cestrifolia Schott] and aquatic macrophytes such as Ranunculus apiifolius Pers., Hydrocotyle ranunculoides L. F., Centella asiatica (L.) Urb., Enydra sp., Scirpus spp., Sagittaria montevidensis Cham. \& Schltdl., Senecio bonariensis Hook. \& Arn., Bromelia anthiacantha Bertol. and Eryngium pandalifolium Cham. \& Schltdl. A regular period of annual flood occurs from May to November, with a maximum measured water level of $45 \mathrm{~cm}$ (Quintela et al., 2012). The sampling period ranged from January 2008 to May 2010.

The other sampled area is a saltmarsh and adjacent restinga sandy forest located in Torotama Island, Patos Lagoon estuary (32 ${ }^{\circ} 03^{\prime}$ 'S; 52 $13^{\circ}$ 'W) (Fig. 1). Vegetation on saltmarsh is composed mainly by Spartina alterniflora Loisel. and Juncus sp. while Ficus sp., Syagrus romanzoffiana, Myrsine parvifolia DC. and Bromelia antiacantha are representative species in the sandy forest. Sampling period for this area lasted from July 2008 to October 2009. The identification of scats was based on the presence and analysis of guard hairs and its association with footprints in the study area. Other carnivores found in the study area were the crab-eating fox Cerdocyon thous( Linnaeus, 1766), the Azara's fox Lycalopex gymnocercus (G. Fischer, 1814), the Geoffroy's cat Leopardus geoffroyi (d'Orbigny \& Gervais, 1844) and the river otter Lontra longicaudis (Olfers, 1818). Procyon cancrivorus guard hairs differed from $C$. thous by its longer length (longest length $56 \mathrm{~mm}$ in $P$. cancrivorus and $46 \mathrm{~mm}$ in $C$. thous) and higher frequency of bi-banded pattern in samples.
Procyon cancrivorus guard hairs are conspicuously longer than L. gymnocercus guard hairs (31 mm) and the central feomelanic band is comparatively much longer. Guard hairs of L. geoffoyi and L. longicaudis are even shorter (15 mm and $21 \mathrm{~mm}$, respectively). Lontra longicaudis also did not show the banded pattern.

Data sampling. The diet composition of $P$. cancrivorus was determined based on the identification of scat remains. Scats were collected during bimonthly exploratory walks, when latrines and isolated scats were identified. All the scats found were collected, labeled and conserved in $70 \%$ alcohol solution. Afterwards, scats were washed through a $1 \mathrm{~mm}$ sieve and solid remains were screened with the aid of a stereoscopic microscope under a magnification of 20-40x. The consumed taxa were determined based on identification of remains such as seeds, fibers, scales, teeth, vertebrae and other bones, hair, carapaces and other structures which were compared with specimens stored in animal and vegetal reference collection of the study areas. Food items were identified to the lowest possible taxonomic category. The frequency of occurrence (FO) of each food item was calculated by the rate of the number of scats containing such item over the total number of analyzed scats (ERLinge, 1968). We did not find scats in autumn in the estuarine island and a single sample was found in summer in the peat forest, which hindered seasonal analysis.

The relative importance (RI) of each food category (i) (fruits, mollusks, crustaceans, insects, diplopods, scorpions, fishes, amphibians, reptiles, birds, mammals) was verified for each system by the rate of FO of such prey category over the sum of the frequency of occurrence of all food categories: $\mathrm{RI}=(\mathrm{FO} / \mathrm{iFO}) \times 100$. The $\mathrm{RI}$ values of each food category were compared to the mean and the categories with values over the mean were considered frequent (Quintela et al., 2012).

The food niche breadth was calculated for each sampled system. Levins index (KREBS, 1999) was used as a measurement of food niche breadth for all food categories (fruits, mollusks, insects, diplopods, scorpions, crustaceans, fishes, amphibians, reptiles, birds, mammals), given as: $\mathrm{B}_{\mathrm{s}}=(\mathrm{B}-1) /(n-1)$, where $\mathrm{B}_{\mathrm{s}}$ is the standardized niche breath, $\mathrm{B}=1 / \sum p_{i}^{2}$, where $p$ is the frequency of each item in the total sample and $n$ is the total number of food categories. The values of $B_{s}$ vary from zero to one. A value close to one implies in a well-distributed diet (items of distinct categories consumed in equal proportions) while a value close to zero implies that items of few categories were consumed in high proportion and items of most categories were consumed in low proportion. The hypotheses of association between the sampled system (peat forest and estuarine island) and the FO of prey categories were tested with a Chi-square.

We evaluated diet similarity between the two sampled areas by using Pianka's index, $O_{j k}=\sum p_{i j} p_{i k} /\left(\sum\right.$ $\left.p_{i j}{ }^{2} \sum p_{i k}{ }^{2}\right)^{1 / 2}$, where $p i$ is the frequency of occurrence of food item $i$ in the diet of systems $j$ and $k$ (Pianka, 1973). 


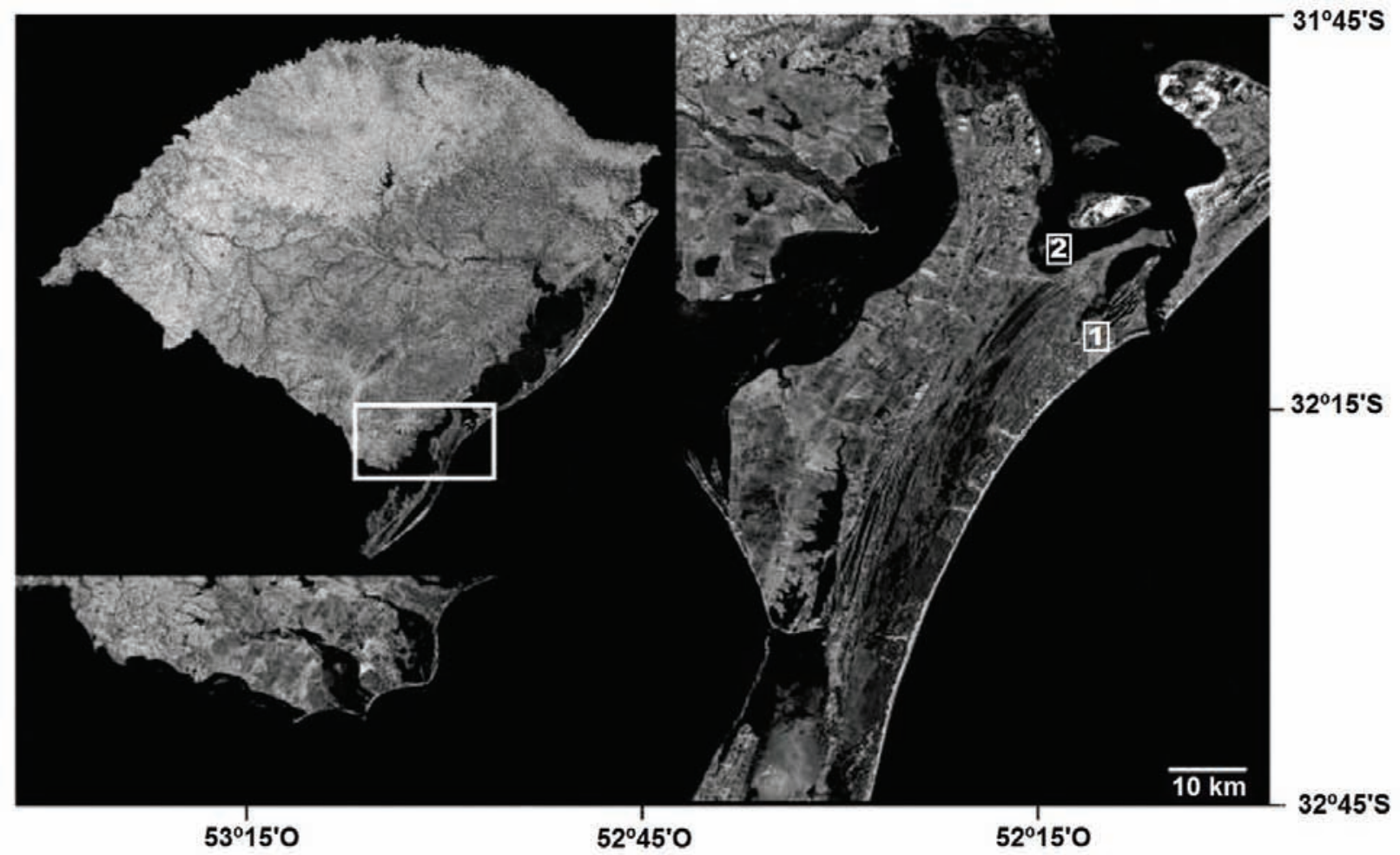

Fig. 1. Location map of the study area, municipality of Rio Grande, state of Rio Grande do Sul, southern Brazil (1, restinga peat forest; 2, estuarine island).

Pianka's index $(O)$ varies between 0 (total separation) and 1 (total overlap).

\section{RESULTS}

A total of 129 scats containing 34 identified taxa was found in the restinga peat forest (Tab. I), seven (20.5\%) of these compassing vegetal items and 27 (79.5\%) compassing animal items. Fruits were the most found item, followed by insects, mollusks, mammals, reptiles, crustaceans, birds, amphibians, fishes, diplopods and scorpions (Tab. I; Fig. 2). Fruits, mollusks, insects, reptiles and mammals were considered frequent items accordingly to RI indexes (Tab. II).

A total of 108 scats containing 25 identified taxa was found in the estuarine island (Tab. I), five (20\%) of these compassing vegetal items and 20 (80\%) compassing animal items. Mammals were the most found item, followed by fruits, crustaceans, reptiles, birds, insects, mollusks, fishes, amphibians and diplopods (Tab. I; Fig. 2). Fruits, crustaceans, reptiles and mammals were considered frequent food categories accordingly to RI indexes (Tab. II).

Values of Levins niche breadth were 0.38 for peat forest and 0.45 for estuarine island. The Chi-square test indicated the existence of association between the sampled system and the frequency of occurrence of food categories $\left(X^{2}=59.69, p<0.001\right)$. Pianka's diet similarity index between the two sampled areas was 0.80 .

\section{DISCUSSION}

The crab-eating raccoon showed a large dietary spectrum on the studied systems, consuming items which ranged from fruits and small invertebrates to mediumsized vertebrates. Values of niche breadth indicated an intermediate niche between a specialist and a well distributed dietary pattern. Procyon cancrivorus is classified as “frugivorous-omnivorous" (Pellanda et al., 2010; Paglia et al., 2012) and the results herein presented corroborates to this classification. The Pianka's index recorded indicated a considerable similarity on diet between the two studied systems. However, discrepancies were found on categories pointed as frequent on each area, as indicated by the Chisquare test. The differences observed on diet composition and frequency of occurrence of food categories may be a reflex of dissimilarities on availability and abundance of potential food resources in the two distinct systems. These dietary adaptations indicate opportunistic habits, a characteristic also pointed by AguiAr et al. (2011).

Considering both studied systems, 35 out of 42 food items identified from $P$. cancrivorus analyzed scats corresponded to animal taxa. However, despite of the relative low representativeness of vegetal items on total richness, these totaled a high frequency of occurrence. The gerivá palm Syagrus romanzoffiana is a common species in original arboreal formations of Rio Grande do Sul coastal plain (RAMBO, 1994) and produces fruits during most of 


\section{Peat forest}

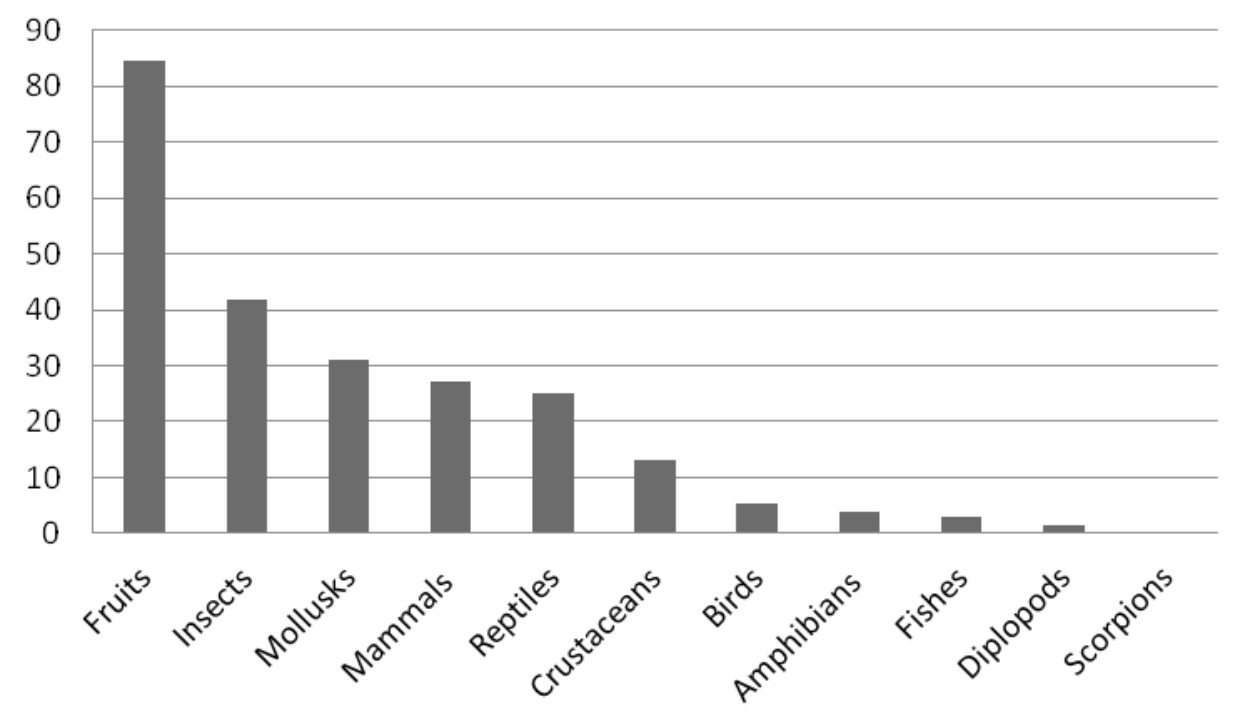

Estuarine island

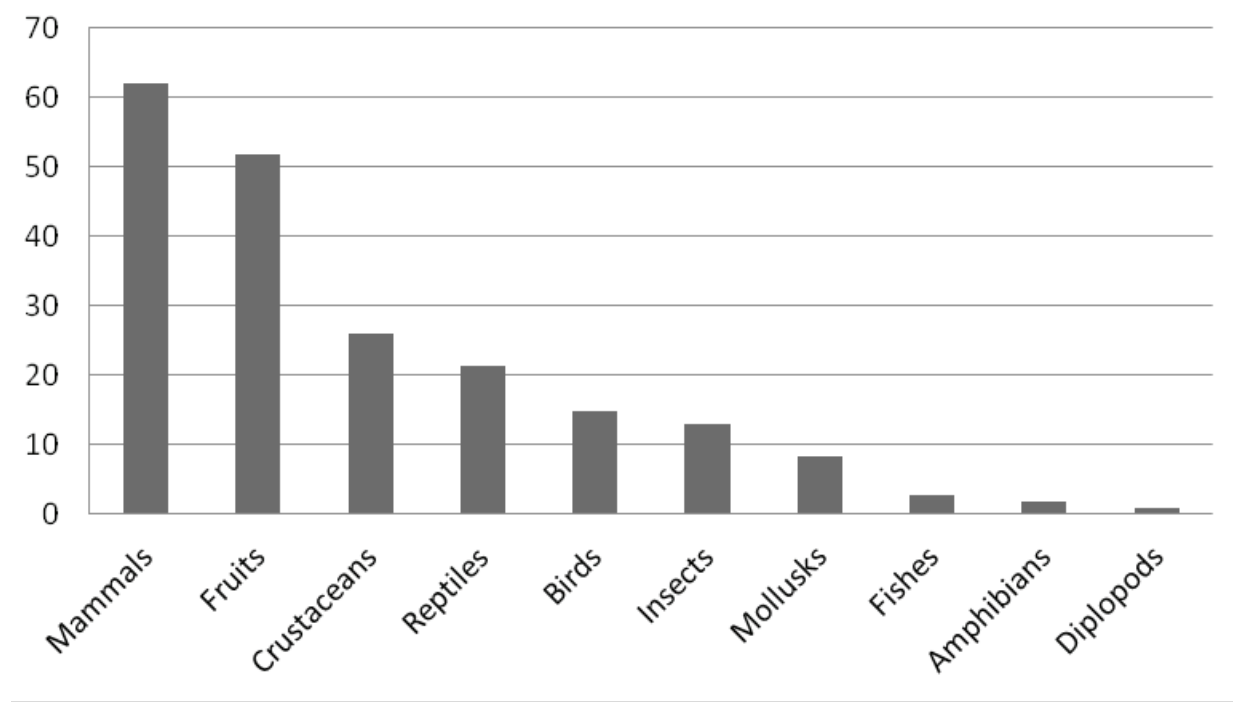

Fig. 2. Frequency of occurrence of food categories identified in Procyon cancrivorus (G. Cuvier, 1798) in a restinga peat forest and an estuarine island in state of Rio Grande do Sul, southern Brazil.

the year (Liebsch \& Miкich, 2009). Fruits of this palm represented an important resource in the peat forest habitat, occurring in $69 \%$ of the analyzed scats. This palm species was also the most consumed item in the northern segment of Rio Grande do Sul coastal plain (SAntos \& Hartz, 1999; Pellanda et al., 2010) and a representative item in $P$. cancrivorus diet in altered Atlantic Forest landscapes in state of Paraná (Aguiar et al., 2011). Therefore, Procyon cancrivorus may play role as seed disperser of Syagrus and other species (i.e. Smilax, Diospyros, Solanum, Psidium) in palustrine forest systems, collaborating to arboreal regeneration. Psidium sp., Smilax sp. and Solanum sp. were also found in low frequencies in previous studies on P. cancrivorus diet (Santos \& Hartz, 1999; Pellanda et al., 2010; Aguiar et al., 2011).

The banana do mato ("wild banana") Bromelia antiacantha is a bromeliad distributed in restingas and forests from southern Brazil to Uruguay (Sмiтн \& Downs, 1979) and produces fruits most part of the year (GIEHL, 2012). Fruits of $B$. antiacantha represented important food resource in the studied estuarine island and was also found by SANTOS \& Hartz (1999), but in low frequency of occurrence. Procyon cancrivorus may also contribute to this species dispersion, as well as to the dispersion of Syagrus, Psidium, Solanum and other species in estuarine communities.

Mammals comprehended the most consumed category in the studied estuarine island and a frequent 
Tab. I. Food items found in Procyon cancrivorus (G. Cuvier, 1798) scats from a restinga peat forest fragment and an estuarine island in state of Rio Grande do Sul, southern Brazil, and its respective absolute occurrence (number of scats containing such item) and frequency of occurrence (between parentheses; rate of the number of scats containing such item over the total number of analyzed scats). Numbers in bold indicate absolute and frequency of occurrence (between parentheses) of food categories (see Material and methods section). Number of samples is indicated below each environment name.

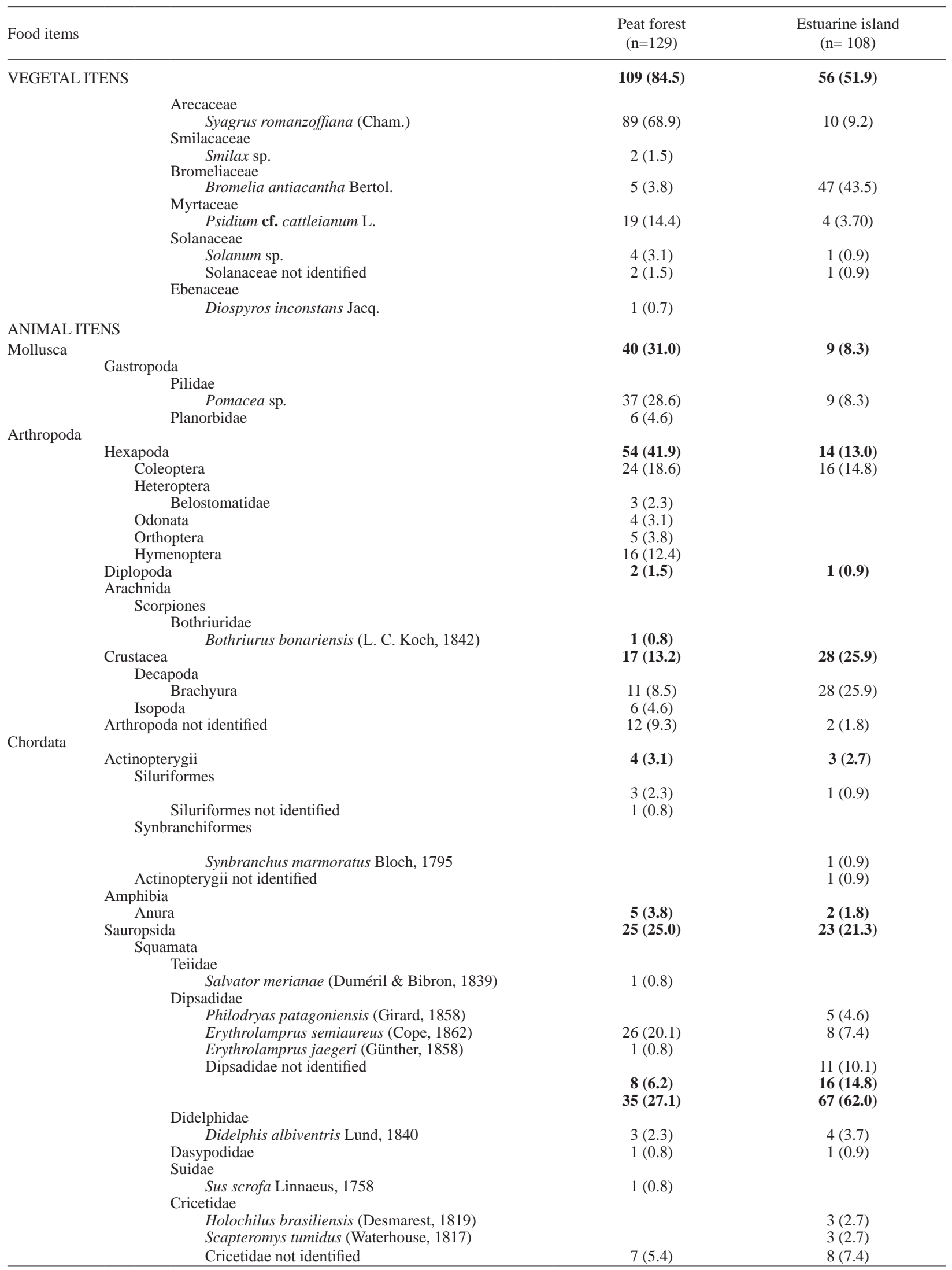


Tab. I. (cont.)

\author{
Caviidae \\ Cavia sp. \\ Chordata not identified
}

$23(21.2)$

$1(0.8)$

$2(1.5)$

$20(15.5)$

$1(0.8)$
$30(27.7)$

$3(2.7)$
Tab. II. Values of relative importance of food categories in the diet of Procyon cancrivorus (G. Cuvier, 1798) from a restinga peat forest fragment and an estuarine island in state of Rio Grande do Sul, southern Brazil. Frequent categories are marked in bold.

\begin{tabular}{lcc}
\hline Food categories & Peat forest & Estuarine island \\
\hline Fruits & $\mathbf{3 5 . 6 4}$ & $\mathbf{2 5 . 6 0}$ \\
Mammals & $\mathbf{1 1 . 4 3}$ & $\mathbf{3 0 . 5 9}$ \\
Insects & $\mathbf{1 7 . 6 7}$ & 6.41 \\
Mollusks & $\mathbf{1 3 . 0 7}$ & 4.09 \\
Reptiles & $\mathbf{1 0 . 5 4}$ & $\mathbf{1 0 . 5 1}$ \\
Crustaceans & 5.57 & $\mathbf{1 2 . 8 3}$ \\
Birds & 2.19 & 7.30 \\
Amphibians & 1.60 & 0.89 \\
Fishes & 1.31 & 1.33 \\
Diplopods & 0.63 & 0.44 \\
Scorpions & 0.34 & 0 \\
\hline
\end{tabular}

category in the peat forest. Considering both systems, mammalian items consisted from small Sigmodontinae rodents to medium-sized species such as armadillos and coypus [Myocastor coypus (Molina, 1782)]. It should also be noted the relative high frequency of cavies (Cavia sp.) and the occurrence of remains of a fossorial hystricomorph (Ctenomys sp.). Mammals were found on varied frequencies on $P$. cancrivorus previous diet investigations and most of the items were represented by small rodents (SANTOS \& Hartz, 1999; GatTi et al., 2006; Pellanda et al., 2010; Aguiar et al., 2011). Medium-sized mammalian preys previously recorded consisted on Dasypus sp. (armadillo) identified by GatTi et al. (2006). The presence of S. scrofa Linnaeus, 1758 (boar, domestic pig) may also be related to scavenging habits, as also observed on diet of other neotropical medium-sized carnivorans such as the crabeating fox Cerdocyon thous Linnaeus, 1766 (FACURE \& Monteiro-Filho, 1996) and Lontra longicaudis Olfers, 1818 (KASPER et al., 2004; QUinTELA et al., 2008).

Frequent invertebrate categories comprehended insects and mollusks in the peat forest and crustaceans in the estuarine island. These results may reflect the abundance of these items observed on each system. A large number of insects and mollusks (mainly Pomacea sp.) were indirectly captured during faunal inventories performed in the peat forest (Quintela et al., 2007; 2011) while brachyuran crustaceans are abundant on muddy estuarine plans (D'INCAO \& Dumont, 2010). Insects, mainly orthopterans and coleopterans, were also representative on the crab-eating raccoon diet in northern Rio Grande do Sul coastal plain (Santos \& Hartz, 1999; Pellanda et al., 2010), Espírito Santo restinga (GATTI et al., 2006) and Venezuela (BisBaL, 1986). Decapod crustaceans were found on varied proportions on all previous studies of the species diet (Bisbal, 1986; Santos \& Hartz, 1999, Pellanda et al., 2010; Aguiar et al., 2011). Mollusks were recorded in low frequencies in northern Rio Grande do Sul coastal plain (Pellanda et al., 2010), contrasting with our results on the peat forest. The presence of myriapods and scorpions was also determined in low frequencies by Pellanda et al. (2010).

Reptiles, represented mainly by dipsadid snakes, were frequent on both studied systems, differently from the previous investigations (BISBAL, 1986; Santos \& Hartz, 1999; Pellanda et al., 2010; Aguiar et al., 2011). Erythrolamprus semiaureus (Cope, 1862), identified on a high proportion among reptile remains, is a common species in aquatic environments of southernmost coastal Brazil (Quintela \& Loebmann, 2009). Other vertebrates (fishes, amphibians and birds) were found in low frequencies, accordingly with the precedent studies (BISBAL, 1986; Santos \& Hartz, 1999; Gatti et al., 2006; Pellanda et al., 2010; Aguiar et al., 2011).

Procyon cancrivorus presented a diversified diet on the subtropical studied systems, revealing opportunistic feeding habits. In the present study, we detected the utilization of resources from estuarine/palustrine systems (i.e. Brachyura crustaceans, Pomacea sp., belostomatids), restinga forests (S. romanzoffiana, Bromelia antiacantha) and grasslands (i.e. Cavia sp. and Ctenomys sp.), revealing the utilization of distinct physiognomies on the mosaics of the sampled coastal/estuarine zone. As observed by Santos \& Hartz (1999) and Pellanda et al. (2010), the species may play a role as seed disperser, contributing to vegetal regeneration. The conservation of $P$. cancrivorus in southern coastal Brazilian areas, however, is conditioned to the habitat quality, which implies on the availability of mainly native fruit and small mammals species.

Acknowledgements. We are grateful to Chyntia Ibarra (in memorian) and Stefan V. de Oliveira for help in fieldwork; Guilherme Seguer for identification of plant species; Emerson Vieira for critical reading and suggestions to the manuscript and CAPES for the doctoral scholarship granted to the first author. 


\section{REFERENCES}

Aguiar, L. M.; Moro-Rios, R. F.; Silvestre, T.; Silva-Pereira, J. E.; Bilski, D. R.; Passos, F. C.; Sekiama, M. L. \& Rocha, V. L. 2011. Diet of brown-nosed coatis and crab-eating racoons from a mosaic landscape with exotic plantations in southern Brazil. Studies on Neotropical Fauna and Environment 46(3):153-161.

Arispe, R.; Venegas, C. \& Rumiz, D. 2008. Abundancia y patrones de actividad del mapache (Procyon cancrivorus) em um bosque chiquitano de Bolivia. Mastozoologia Neotropical 15(2):323-333.

AraúJo, D. S. D. 1992. Vegetation types of Sandy coastal plains of tropical Brazil: a first approximation. In: SeEliger, U. ed. Coastal Plant Communities of Latin America. New York, Academy Press, p. 337-347.

Bisbal, J. F. 1986. Food habitats of some carnivores in Venezuela (Mammalia, Carnivora). Mammalia 50:329-339.

Cheida, C. C.; Nakano-Oliveira, E.; Fusco-Costa, R.; Rocha-Mendes, F. \& Quadros, J. 2011. Ordem Carnivora. In: Reis, N. R.; Peracchi, A. L.; Pedro, W. A. \& Lima, I. P. eds. Mamíferos do Brasil. Londrina, Nélio dos Reis, p. 235-288.

D’Incao, F. \& Dumont, L. F. C. 2010. A comunidade de crustáceos decápodes. In: Seeliger, U. \& Odebrecht, C. eds. O estuário da Lagoa dos Patos: um século de transformações. Rio Grande, FURG, p. 117-124.

ERLINGE, S. 1968. Food studies on captive otters Lutra lutra L. Oikos 19:259-270.

Fabián, M. E.; SouZa, D. A. S.; Carvalho, F. \& Lima, C. 2011. Mamíferos de áreas de restinga no Rio Grande do Sul. In: PessôA, L. M.; TAVAres, W. C. \& Siciliano, S. eds. Mamíferos de restingas e manguezais do Brasil. Rio de Janeiro, Sociedade Brasileira de Mastozoologia, Museu Nacional, p. 209-224.

Facure, K. G. \& Monteiro-Filho, E. L. A. 1996. Feeding habits of the crab-eating fox, Cerdocyon thous (Carnivora, Canidae), in a suburban area of southeastern Brazil. Mammalia 60:147-149.

Gatti, A.; Bianchi, R.; Rosa, C. R. X. \& Mendes, S. L. 2006. Diet of two sympatric carnivores, Cerdocyon thous and Procyon cancrivorus, in a restinga area of Espírito Santo State, Brazil. Journal of Tropical Ecology 22:227-230.

Gient, E. L. H. 2012. Flora digital do Rio Grande do Sul e de Santa Catarina. Universidade Federal do Rio Grande do Sul. Available at: $<$ http://ufrgs.br/floradigital >. Accessed on: 03 July 2013.

GonzÁlez, E. M. \& LAnfranco, J. A. M. 2010. Mamíferos de Uruguay. Guía de campo e introducción a su estúdio y conservación. Montevideo, Banda Oriental, Museo Nacional de Historia Natural, Vida Silvestre Uruguay. 463p.

Kasper, C. B.; Feldens, M. J.; Salvi, J. \& Grillo, H. C. J. 2004. Estudo Preliminar sobre a ecologia de Lontra longicaudis no Vale do Taquari, Sul do Brasil. Revista Brasileira de Zoologia 21(1):65-72.

KreBs, C. J. 1999. Ecological methodology. Menlo Park, Bejamin, Cummings. 620p.

Liebsch, D. \& Miкich, S. B. 2009. Fenologia reprodutiva de espécies vegetais da Floresta Ombrófila Mista do Paraná. Revista Brasileira de Botânica 32(2):375-391.

Martinelli, M. M. \& Volpi, T. A. 2010. Diet of raccoon Procyon cancrivorus (Carnivora, Procyonidae) in a mangrove and resting area in Espírito Santo state, Brazil. Natureza on line 8(3):150-151.

Morato, R. G; Rodrigues, F. H. G.; Eizirik, E.; Mangini, P. R. \& Azevedo, F. C. C. 2004. Plano de ação: pesquisa e conservação de mamíferos carnívoros no Brasil. Brasília, IBAMA. 52p.
Paglia, A. P.; Fonseca, G. A. B.; Rylands, A. B.; Herrmann, G.; Aguiar, L. M. S.; Chiarello, A. G.; Leite, Y. L. R.; Costa, L. P.; Siciliano, S.; Kierulff, M. C. M.; Mendes, S. L.; Tavares, V. C.; Mittermeier, R. A. \& Patton, J. L. 2012. Annotated Checklist of Brazilian Mammals. Occasional Papers in Conservation Biology 6:1-76.

Pellanda, M.; Almeida, C. M. C.; Santos, M. F. M. \& Hartz, S. M. 2010. Dieta do mão-pelada (Procyon cancrivorus, Procyonidae, Carnivora) no Parque Estadual de Itapuã, sul do Brasil. Neotropical Biology and Conservation 5(3):154-159.

Pianka, E. R. 1973. The structure of lizard communities. Annual Review of Ecology and Systematics 4:53-74.

Quintela, F. M.; Artioli, L. G. S. \& Porciuncula, R. A. 2012. Diet of Lontra longicaudis (Ofers, 1818) (Carnivora: Mustelidae) in three limnic system in southern Rio Grande do Sul State, Brazil. Brazilian Archives of Biology and Technology 55(6):877-886.

Quintela, F. M. \& Loebmann, D. 2009. Guia Ilustrado: Os répteis da região costeira do extremo sul do Brasil. Pelotas, USEB. 84p.

Quintela, F. M.; Pinheiro, R. M. \& Loebmann, D. 2011. Composição e uso do hábitat pela herpetofauna em uma área de mata paludosa da Planície Costeira do Rio Grande do Sul, extremo sul do Brasil. Revista Brasileira de Biociências 9(1):6-11.

Quintela, F. M.; Porciuncula, R. A. \& Colares, E. P. 2008. Dieta de Lontra longicaudis (Olfers) (Carnivora, Mustelidae) em um arroio costeiro da região sul do Estado do Rio Grande do Sul, Brasil. Neotropical Biology and Conservation 3(3):119-125.

Quintela, F. M.; Porciuncula, R. A.; Condini, M. V. L.; Vieira, J. P. \& Loebmann, D. 2007. Composição da ictiofauna durante o período de alagamento em uma mata paludosa da planície costeira do Rio Grande do Sul, Brasil. Pan-American Journal of Aquatic Sciences 2(3):191-198.

Quintela, F. M.; Santos, M. B.; Christoff, A. U. \& Gava, A. 2012. Pequenos mamíferos não-voadores (Didelphimorphia, Rodentia) em dois fragmentos de mata de restinga de Rio Grande, Planície Costeira do Rio Grande do Sul. Biota Neotropica 12(1):261-266.

Rambo, B. 1994. A fisionomia do Rio Grande do Sul. São Leopoldo, Unisinos. 473p

Roemer, G. W.; Gomprer, M. E. \& Van Valkenburgh, B. 2009.The ecological role of the mammalian mesocarnivore. BioScience 59(2):165-173.

Santos, M. \& Hartz, S. M. 1999.The food habits of Procyon cancrivorus (Carnivora, Procyonidae) in the Lami Biological Reserve, Porto Alegre, Southern Brazil. Mammalia 63:525-530.

Scherer, A.; Maraschin-Silva, F. \& Baptista, L. R. M. 2005. Florística e estrutura do componente arbóreo de matas de Restinga arenosa no Parque Estadual de Itapuã, RS, Brasil. Acta Botanica Brasilica 19(4):717-726.

Seeliger, U. 2010. Introdução In: Seeliger, U. \& Odebrecht, C. eds. O estuário da Lagoa dos Patos: um século de transformações. Rio Grande, FURG, p. 11-16.

Smith, L. B. \& Downs, R. J. 1979. Bromelioideae (Bromeliaceae). Flora Neotropica Monograph 14:1493-2142.

VAn Valkenburgh, B. 2007. Déjà vu: the evolution of feeding morphologies in the Carnivora. Integrative and Comparative Biology 47(1):147-163.

VIEIRA, E. F. 1983. Rio Grande: geografia física, humana e econômica. Porto Alegre, Sagra. 158 p.

WAEChTER, J. L. 1985. Aspectos ecológicos da vegetação de restinga no Rio Grande do Sul, Brasil. Comunicações do Museu de Ciências e Tecnologia PUCRS, Série Botânica 33:49-68. 